Tropical Journal of Pharmaceutical Research May 2017; 16 (5): 989-996

ISSN: $1596-5996$ (print); 1596-9827 (electronic)

(C) Pharmacotherapy Group, Faculty of Pharmacy, University of Benin, Benin City, 300001 Nigeria.

All rights reserved.

Available online at http://www.tjpr.org

Original Research Article

http://dx.doi.org/10.4314/tjpr.v16i5.4

\title{
Antihyperglycaemic and hypolipidemic effect of methanol extracts of Ageratum conyzoides L (Asteraceae) in normal and diabetic rats
}

\author{
Sunday E Atawodi*, Oluwafemi A Adepoju and Humphrey C Nzelibe \\ Biochemistry Department, Ahmadu Bello University, Zaria, Nigeria
}

*For correspondence: Email: atawodi_se@yahoo.com; Tel: +2348033850613

Sent for review: 30 June 2016

Revised accepted: 6 April 2017

\begin{abstract}
Purpose: To investigate the antihyperglycaemic and hypolipidemic potential of the methanol extracts of leaf, stem and root of Ageratum conyzoides in streptozotocin (STZ)-induced diabetic rats.

Methods: The extract of each of the plant part was obtained by extraction in methanol. A total of 60 male Wistar albino rats (30 induced with diabetes and 30 normoglycaemic) were assigned into diabetic and normoglycaemic groups of 6 rats each. Methanol extracts of leaf, stem and root of Ageratum conyzoides were administered orally at a dose of $100 \mathrm{mg} / \mathrm{kg}$ to the rats for a period of 14 days, with glibenclamide as the standard drug $(1 \mathrm{mg} / \mathrm{kg})$. Fasting blood glucose and lipid profile were determined to ascertain the antihyperglycaemic and hypolipidemic activities of the different parts of the plant.

Results: Ageratum conyzoides significantly $(p<0.05)$ reduced fasting blood glucose (FBG) levels in diabetic rats by $38.71 \pm 19.41 \%$ (leaf), $25.64 \pm 20.53 \%$ (stem), and $34.76 \pm 18.03 \%$ (root) on day 14 of the treatment, compared with untreated diabetic rats where FBG increased by $11.33 \pm 8.91 \%$. Total cholesterol (leaf, $119.10 \pm 8.12 \mathrm{mg} / \mathrm{dl}$; stem, $109.28 \pm 8.13 \mathrm{mg} / \mathrm{dl}$ ) and triglycerides (leaf, $61.71 \pm 9.37$ $\mathrm{mg} / \mathrm{dl}$; stem, $72.45 \pm 3.39 \mathrm{mg} / \mathrm{dl})$ levels were also significantly $(p<0.05)$ lowered in diabetic rats. Low density lipoprotein cholesterol (leaf, $77.21 \pm 8.12 \mathrm{mg} / \mathrm{dl}$; stem, $64.76 \pm 8.04 \mathrm{mg} / \mathrm{dl}$; root, $79.08 \pm 10.61$ $\mathrm{mg} / \mathrm{dl})$ levels were significantly $(p<0.05)$ lowered in all treated diabetic groups compared with the untreated diabetic rats $(103.19 \pm 6.08 \mathrm{mg} / \mathrm{dl})$.

Conclusion: The results from this study indicate that Ageratum conyzoides has hypoglycaemic and hypolipidemic properties in rats, and this probably justifies its reported use in the traditional management of diabetes mellitus.
\end{abstract}

Keywords: Ageratum conyzoides, Diabetes mellitus, Antihyperglycaemic, Hypolipidemic

Tropical Journal of Pharmaceutical Research is indexed by Science Citation Index (SciSearch), Scopus, International Pharmaceutical Abstract, Chemical Abstracts, Embase, Index Copernicus, EBSCO, African Index Medicus, JournalSeek, Journal Citation Reports/Science Edition, Directory of Open Access Journals (DOAJ), African Journal Online, Bioline International, Open-J-Gate and Pharmacy Abstracts

\section{INTRODUCTION}

Early diagnosis and reduction of hyperglycemia, a hallmark of diabetes, can reduce much of the excess morbidity and mortality associated with diabetes mellitus. Increasing evidence indicates that the complications of diabetes are preventable by controlling the metabolic abnormalities but oral hypoglycaemic drugs developed to manage diabetes are not without side effects. Problems associated with the current diabetic pharmacotherapy such as hypoglycaemia, weight gain, lactic acidosis, skin reactions, acute porphyria and abdominal discomfort [1] have further necessitated the need to search for more effective and safer approach to pre-diabetic and diabetic management [2].

Plants provide an alternative strategy in search for new drugs. The reducing effect of blood 
glucose by a large number of plants have been confirmed in animal models and clinical studies [3]. Ageratum conyzoides is an annual herb with long history of traditional medicinal uses in many countries in the world. In traditional medicine, Ageratum conyzoides is used for the treatment of several diseases including diabetes [4]. For instance, aqueous extract of the whole part of the plant has been used as a dermatological remedy, while ethyl acetate extract has been shown to possess anti-cancerous and radical scavenging properties [5]. Similarly, the anti-inflammatory, antifungal and schistosomicidal properties of the plant have been reported [6-8]. Studies have also demonstrated the antioxidant activity, insecticidal activities and larvicidal effect of the plant extracts $[9,10]$. In this study we explored the antihyperglycaemic and hypolipidemic potential of Ageratum conyzoides in streptozotocininduced diabetic rats.

\section{EXPERIMENTAL}

\section{Chemical}

Streptozotocin (STZ) and methanol were purchased from Sigma Chemical Company St. Louis U.S.A. All assay kits were from Randox Laboratories Limited UK. All other chemicals (sodium citrate, chloroform) and reagents used were of analytical grade obtained from reputable manufacturers.

\section{Plant collection and identification}

Fresh Ageratum conyzoides plants were collected from an uncultivated farmland in Samaru, Zaria, Kaduna State, Nigeria in the month of July 2012. Sample was identified and authenticated at the Herbarium Unit of the Department of Biological Sciences, Ahmadu Bello University, Zaria by Mr. Gallah U.J, a taxonomist, where a voucher specimen (no. 261) has been kept for future reference.

\section{Experimental animals}

Adult albino rats of either sexes weighing between 150 - $200 \mathrm{~g}$ were obtained from the Animal House, Department of Pharmacology, Ahmadu Bello University, Zaria. The animals were acclimatized in well ventilated cages under ambient environmental conditions for a period of two weeks before commencement of experiment. They were maintained on grower's mash (Vital Feeds Grand Cereal Plc, Bukuru, Jos, Plateau State) and provided with water ad libitum. All the experiments were conducted in accordance with international laboratory animal use and care guidelines [11]. Study protocols and ethical issues were approved by the Animal Research and Ethical Committee of Ahmadu Bello University, Zaria, Nigeria with ref no. ABUAREC/124/2012.

\section{Preparation and extraction of plant materials}

Fresh Ageratum conyzoides plants were separated into leaves, stems and roots, rinsed in clean water and dried under ambient temperature until brittle. The dry samples were ground separately into powder using mortar and pestle. Each of the powdered materials (250 g) was extracted with $1.0 \mathrm{~L}$ of methanol by cold maceration for $48 \mathrm{~h}$ in large amber bottles with intermittent shaking. The crude methanol extracts were filtered and concentrated to dryness using rotary evaporator at $45{ }^{\circ} \mathrm{C}$. The concentrated extracts were stored in air-tight sample bottles in a refrigerator until required for use.

\section{Phytochemical screening}

Qualitative phytochemical screening for alkaloids, carbohydrates, cardiac glycosides, anthracene, flavonoids, saponins, tannins, steroids and triterpenes was carried out on the leaf, stem and root extracts by the methods described by Trease and Evans [12].

\section{Induction of diabetes}

Diabetes was induced in rats fasted overnight by a single intraperitoneal injection of freshly prepared solution of streptozotocin (Sigma Chemicals Co., St Loius USA) at $60 \mathrm{mg} / \mathrm{kg}$ in 0.1 $\mathrm{M}$ cold citrate buffer $\mathrm{pH}$ 4.5. The animals were considered as diabetic if the blood glucose values of the overnight fasted rats, were $>200$ $\mathrm{mg} / \mathrm{dl}$ on the third day following streptozotocin injection [13].

\section{Animal grouping and treatment}

A total of 60 rats were randomly divided into 10 groups of 6 rats each as follows: normal control (feed and water only), untreated diabetic (diabetic control), diabetic + leaf extract (100 $\mathrm{mg} / \mathrm{kg}$ ), diabetic + stem extract $(100 \mathrm{mg} / \mathrm{kg})$, diabetic + root extract $(100 \mathrm{mg} / \mathrm{kg})$, diabetic + glibenclamide (1 $\mathrm{mg} / \mathrm{kg})$, normoglycaemic + leaf extract $(100 \mathrm{mg} / \mathrm{kg})$, normoglycaemic + stem extract $(100 \mathrm{mg} / \mathrm{kg})$, normoglycaemic + root extract $(100 \mathrm{mg} / \mathrm{kg})$, normoglycaemic + glibenclamide (1 $\mathrm{mg} / \mathrm{kg}$ ) [14]. Treatment was orally administered daily for a period of 14 days.

\section{Blood glucose determination}


The fasting blood glucose was determined as described by Clark and Lyons [15] using glucometer. The test is based on the principle that the test strip has a small spot impregnated with glucose oxidase and other components. The glucose in the blood sample reacts with the glucose oxidase to form gluconic acid, which then reacts with ferricyanide to form ferrocyanide. The electrode oxidizes the ferrocyanide, and this generates a current directly proportional to the glucose concentration. The total charge passing through the electrode is proportional to the amount of glucose in the blood that has reacted with the enzyme. The change in this parameter $(G)$ was calculated using Eq 1.

$G(\%)=\left\{\left(G_{f}-G_{i}\right) / G i\right\} 100$

where $G_{i}$ and $G_{f}$ are the initial and final fasting blood glucose respectively.

\section{Collection of blood for analyses}

At the end of 14 days of treatment, the animals were anaesthetized with chloroform and sacrificed by decapitation. The blood of each animal was separately collected in nonheparinised tubes and allowed to clot. Serum was harvested following centrifugation at 3000 rpm for $15 \mathrm{~min}$ and was used for biochemical analyses.

\section{Determination of serum total cholesterol (TC)}

Cholesterol in the blood is oxidized by cholesterol oxidase to yield hydrogen peroxide. Serum cholesterol was quantified spectrophotometrically by measuring the absorbance of the indicator, quinoneimine, formed from hydrogen peroxide and 4aminoantipyrine in the presence of phenol and peroxidase as described by Stein [16].

The assay mixture contained $10 \mu \mathrm{l}$ of test serum and $1 \mu \mathrm{l}$ of cholesterol reagent in a test tube. The mixture was incubated at $37^{\circ} \mathrm{C}$ for $5 \mathrm{~min}$ in a water bath. The absorbance of the sample $\left(A_{t}\right)$ and that of the standard $\left(A_{s}\right)$ were measured against the reagent blank at $500 \mathrm{~nm}$ wavelength. The values obtained were used to calculate total cholesterol concentration as in Eq 2.

$\mathrm{TC}(\mathrm{mg} / \mathrm{dl})=\left(\mathrm{A}_{\mathrm{t}} / \mathrm{A}_{\mathrm{s}}\right) \mathrm{C}$

where $T C=$ total cholesterol, $A_{t}=$ absorbance of sample and $A_{s}=$ absorbance of standard.

\section{Determination of serum triglycerides (TG)}

The serum triglycerides (TG) level was determined by enzymatic method described by Stein [16]. One millilitre of the randox TG enzyme reagent (containing a mixture of lipases, glycerolkinase, ATP, 4-aminophenazone, 4chlorophenol, peroxidise, glycerol-3-phosphate oxidase and magnesium ions) was dispensed into three separately labelled test tubes; standard, sample and reagent blank. The standard contained $10 \mu \mathrm{l}$ standard triglyceride, the tube labelled sample contained $10 \mu \mathrm{l}$ test serum while that labelled reagent blank was empty. The mixture was incubated for $5 \mathrm{~min}$ at $37^{\circ} \mathrm{C}$ in a water bath. After the period of incubation the absorbance of the sample and that of the standard was read against the reagent blank within 60 min using a colorimeter at 500 $\mathrm{nm}$ wavelength. The triglyceride concentration was calculated as in Eq 3.

$\mathrm{TG}(\mathrm{mg} / \mathrm{dl})=\left(\mathrm{A}_{\mathrm{t}} / \mathrm{A}_{\mathrm{s}}\right) \mathrm{C}$

where $T G=$ triglycerides, $A_{t}=$ absorbance of sample and $A_{s}=$ absorbance of standard.

\section{Determination of serum high density lipoprotein-cholesterol (HDL-C)}

Serum level of HDL-C was estimated as described by Wacnic and Albers [17]. The Assay principle is based on the quantitative precipitation of low density lipoproteins (LDL and VLDL) and chylomicron fractions by the addition of $0.5 \mathrm{ml}$ of reagent 1 (R1) which is made up of phosphortungstic acid and magnesium chloride to $0.2 \mathrm{ml}$ of the sample. The resulting mixture from this reaction was centrifuged at $4000 \mathrm{rpm}$ for $10 \mathrm{~min}$ and the supernatant was collected. The cholesterol concentration in the HDL fraction, which remains in the supernatant was determined by adding $1.0 \mathrm{ml}$ of reagent 2 (cholesterol reagent) into clean test tubes containing $0.05 \mathrm{ml}$ of sample supernatant, 0.05 $\mathrm{ml}$ standard supernatant and an empty test tube (reagent blank), mixed thoroughly and incubated for $30 \mathrm{~min}$ at room temperature. The absorbance was read against the reagent blank at $500 \mathrm{~nm}$ within $60 \mathrm{~min}$.

The concentration of HDL-C was calculated as in Eq 4.

HDL-C $(\mathrm{mg} / \mathrm{dl})=\left(\Delta \mathrm{A}_{\mathrm{t}} / \Delta \mathrm{A}_{\mathrm{s}}\right) \mathrm{C}$

where $\mathrm{HDL}-\mathrm{C}=$ high density lipoprotein cholesterol, $\Delta \mathrm{A}_{t}=$ change in absorbance of sample, and $\Delta \mathrm{A}_{\mathrm{s}}=$ change in absorbance of standard. 


\section{Determination of serum low density lipoprotein-cholesterol (LDL-C)}

The serum level of low density lipoproteincholesterol (LDL-C) was estimated as described by Friedewald et al as in Eq 5 [18].

LDL-C $(\mathrm{mg} / \mathrm{dl})=\mathrm{TC}-\mathrm{TG} / 5-\mathrm{HDL}-\mathrm{C}$

where $\mathrm{LDL}-\mathrm{C}=$ low density lipoprotein cholesterol, $\mathrm{TC}=$ total cholesterol, $\mathrm{TG}=$ triglycerides, $\mathrm{HDL}-\mathrm{C}=$ high density lipoprotein cholesterol.

\section{Statistical analysis}

The data were analyzed using ANOVA and expressed as mean \pm SD except where otherwise stated. The differences in means were compared using Duncan Multiple Range Test. A value of $p<0.05$ was considered to indicate a significant difference between groups.

\section{RESULTS}

\section{Extract yield}

The yields of methanol leaf, stem and root extracts of Ageratum conyzoides were $7.65 \%$, $4.70 \%$ and $2.85 \%$, respectively.

\section{Phytochemical constituents of Ageratum conyzoides}

The phytochemical screening revealed the presence of alkaloids, carbohydrates, cardiac glycosides, flavonoids, saponins, tannins, steroids and triterpenes in the extracts (Table 1).

Effect of different parts of Ageratum conyzoides on fasting blood glucose (FBG)

Ageratum conyzoides significantly $(p<0.05)$ reduced blood glucose levels in treated diabetic groups in comparison with the diabetic control. On the 14th day of the experiment, the fasting blood glucose (FBG) showed 38.71, 25.64, 34.76 and $34.39 \%$ reduction in blood glucose by the leaf, stem, root and glibenclamide treated diabetic groups respectively against the increase of $11.33 \%$ seen in the negative control group. The leaf extract had the highest reducing effect on fasting blood glucose. There was no significant $(p>0.05)$ change in blood glucose levels of normoglycaemic rats treated with extracts of Ageratum conyzoides (Table 2).

Table 1: Phytochemical constituents of methanol extracts of Ageratum conyzoides

\begin{tabular}{llll}
\hline Phytochemical & Leaf & Stem & Root \\
\hline Alkaloids & + & + & + \\
Carbohydrates & + & + & + \\
Cardiac glycosides & + & + & + \\
Anthracene & - & - & + \\
Flavonoids & + & + & + \\
Saponins & + & + & + \\
Tannins & + & + & - \\
Steroid & + & - & + \\
Triterpenes & + & + &
\end{tabular}

Table 2: Fasting blood glucose level of streptozotocin-induced diabetic and normoglycaemic rats treated with 100 $\mathrm{mg} / \mathrm{kg}$ methanol leaf, stem and root extracts of Ageratum conyzoides

\begin{tabular}{|c|c|c|c|c|}
\hline \multirow[t]{2}{*}{ Treatment } & \multicolumn{3}{|c|}{ Fasting blood glucose (mg/dL) } & \multirow{2}{*}{$\begin{array}{c}\% \text { Change } \\
\text { (Day 14) }\end{array}$} \\
\hline & Day 0 & Day 7 & Day 14 & \\
\hline Normal Control & $87.83 \pm 13.85^{a}$ & $79.17 \pm 3.54^{\mathrm{a}}$ & $86.00 \pm 9.70^{a}$ & $+0.91 \pm 23.33^{c}$ \\
\hline Diabetic + Untreated & $284.33 \pm 55.23^{b}$ & $310.17 \pm 61.72^{\mathrm{c}}$ & $315.83 \pm 62.37^{\mathrm{C}}$ & $+11.33 \pm 8.91^{\mathrm{c}}$ \\
\hline Diabetic + Leaf & $321.50 \pm 94.14^{b}$ & $255.33 \pm 93.61^{\mathrm{bc}}$ & $192.67 \pm 82.2^{\mathrm{b}}$ & $-38.71 \pm 19.41^{\mathrm{a}}$ \\
\hline Diabetic + Stem & $254.50 \pm 61.10^{b}$ & $218.00 \pm 63.69^{b}$ & $184.80 \pm 58.34^{\mathrm{b}}$ & $-25.64 \pm 20.53^{\mathrm{ab}}$ \\
\hline Diabetic + Root & $302.67 \pm 45.72^{b}$ & $270.50 \pm 63.43^{\mathrm{bc}}$ & $202.33 \pm 82.69^{b}$ & $-34.76 \pm 18.03^{\mathrm{a}}$ \\
\hline Diabetic + Glib & $294.33 \pm 49.31^{\mathrm{b}}$ & $241.67 \pm 62.78^{\mathrm{bc}}$ & $188.83 \pm 64.69^{\mathrm{b}}$ & $-34.39 \pm 23.33^{a}$ \\
\hline Normoglycaemic+Leaf & $88.17 \pm 19.15^{\mathrm{a}}$ & $80.33 \pm 19.34^{\mathrm{a}}$ & $82.83 \pm 5.27^{\mathrm{a}}$ & $-3.27 \pm 15.95^{\mathrm{bc}}$ \\
\hline Normoglycaemic+Stem & $90.00 \pm 9.42^{\mathrm{a}}$ & $83.17 \pm 11.57^{\mathrm{a}}$ & $83.00 \pm 8.90^{\mathrm{a}}$ & $-7.46 \pm 8.66^{\mathrm{bc}}$ \\
\hline Normoglycaemic+Root & $98.00 \pm 12.14^{\mathrm{a}}$ & $91.33 \pm 11.86^{\mathrm{a}}$ & $93.33 \pm 8.43^{\mathrm{a}}$ & $-3.25 \pm 17.82^{\mathrm{DC}}$ \\
\hline Normoglycaemic+Glib & $94.50 \pm 13.49^{\mathrm{a}}$ & $88.33 \pm 9.41^{\mathrm{a}}$ & $90.00 \pm 7.84^{\mathrm{a}}$ & $-3.54 \pm 13.27^{\mathrm{bc}}$ \\
\hline
\end{tabular}


Table 3: Lipid profile of streptozotocin-induced diabetic and normoglycaemic rats treated with $100 \mathrm{mg} / \mathrm{kg}$ methanol leaf, stem and root extracts of Ageratum conyzoides

\begin{tabular}{|c|c|c|c|c|}
\hline \multirow[t]{2}{*}{ Treatment } & \multicolumn{3}{|c|}{ Lipid profile (mg/dL) } & \multirow[b]{2}{*}{$L D L-C$} \\
\hline & TC & $T G$ & $H D L-C$ & \\
\hline Normal Control & $91.84 \pm 3.70^{\mathrm{ab}}$ & $59.05 \pm 3.53^{\mathrm{ab}}$ & $30.27 \pm 0.47^{b}$ & $49.76 \pm 3.52^{\mathrm{ab}}$ \\
\hline Diabetic + Untreated & $148.88 \pm 7.41^{\mathrm{e}}$ & $100.82 \pm 11.17^{d}$ & $25.52 \pm 1.04^{a}$ & $103.19 \pm 6.08^{\mathrm{e}}$ \\
\hline Diabetic + Leaf & $119.10 \pm 8.12^{\mathrm{cd}}$ & $61.71 \pm 9.37^{\mathrm{ab}}$ & $29.55 \pm 1.00^{\mathrm{b}}$ & $77.21 \pm 8.12^{\mathrm{cd}}$ \\
\hline Diabetic + Stem & $109.28 \pm 8.13^{\mathrm{bcd}}$ & $72.45 \pm 3.39^{\mathrm{abc}}$ & $30.03 \pm 0.52^{b}$ & $64.76 \pm 8.04^{\mathrm{bcd}}$ \\
\hline Diabetic + Root & $128.77 \pm 10.48^{\mathrm{de}}$ & $95.06 \pm 8.73^{\mathrm{cd}}$ & $30.67 \pm 1.57^{\mathrm{b}}$ & $79.08 \pm 10.61^{c a}$ \\
\hline Diabetic + Glib & $127.99 \pm 5.63^{\mathrm{de}}$ & $81.49 \pm 11.69^{\mathrm{bcd}}$ & $29.39 \pm 0.94^{b}$ & $82.31 \pm 5.94^{a}$ \\
\hline Normoglycaemic+Leaf & $95.80 \pm 1.36^{\mathrm{ab}}$ & $62.71 \pm 6.90^{\mathrm{ab}}$ & $31.73 \pm 0.68^{b}$ & $51.53 \pm 2.61^{\mathrm{ab}}$ \\
\hline Normoglycaemic+Stem & $95.36 \pm 11.06^{\mathrm{ab}}$ & $49.78 \pm 7.45^{\mathrm{a}}$ & $32.64 \pm 1.20^{b}$ & $52.77 \pm 10.74^{\mathrm{ab}}$ \\
\hline Normoglycaemic+Root & $103.92 \pm 2.53^{\mathrm{bc}}$ & $72.63 \pm 2.08^{\mathrm{abc}}$ & $31.56 \pm 1.78^{b}$ & $57.84 \pm 2.67^{\mathrm{abc}}$ \\
\hline Normoglycaemic+Glib & $77.92 \pm 6.09^{\mathrm{a}}$ & $60.67 \pm 9.36^{\mathrm{ab}}$ & $29.13 \pm 1.90^{\mathrm{b}}$ & $36.65 \pm 7.89^{\mathrm{a}}$ \\
\hline
\end{tabular}

Values are means $\pm s d, n=6$, values with different superscripts down the column are significantly different ( $p<$ 0.05). ${ }^{a} p<0.01,{ }^{b} p<0.001,{ }^{c} p<0.0001$. TC: Total cholesterol; TG: Triglycerides; HDL-C: High density lipoprotein cholesterol; LDL-C: Low density lipoprotein cholesterol

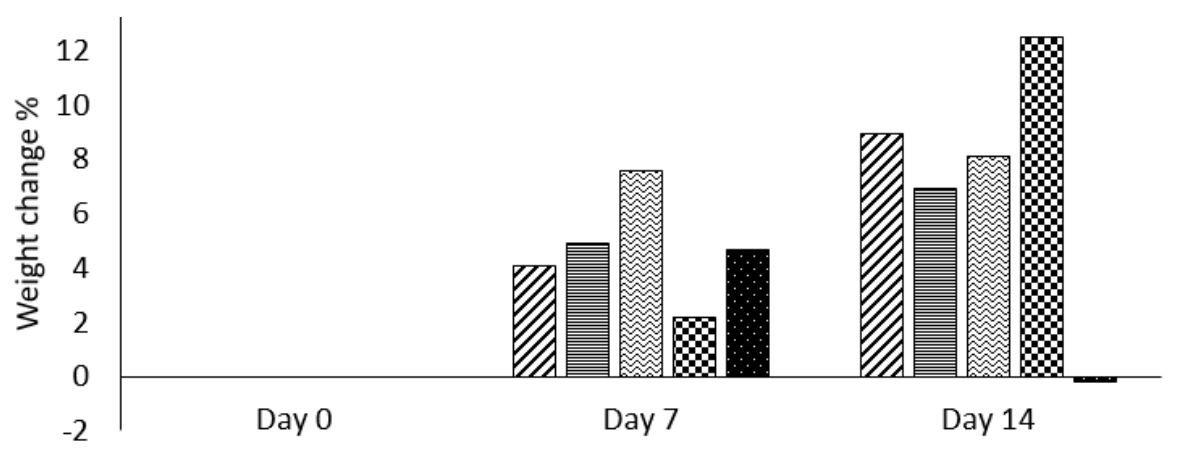

$\mathbb{Z N C}$ 冒 NL 图NS $\mathrm{N} N \mathrm{NG}$

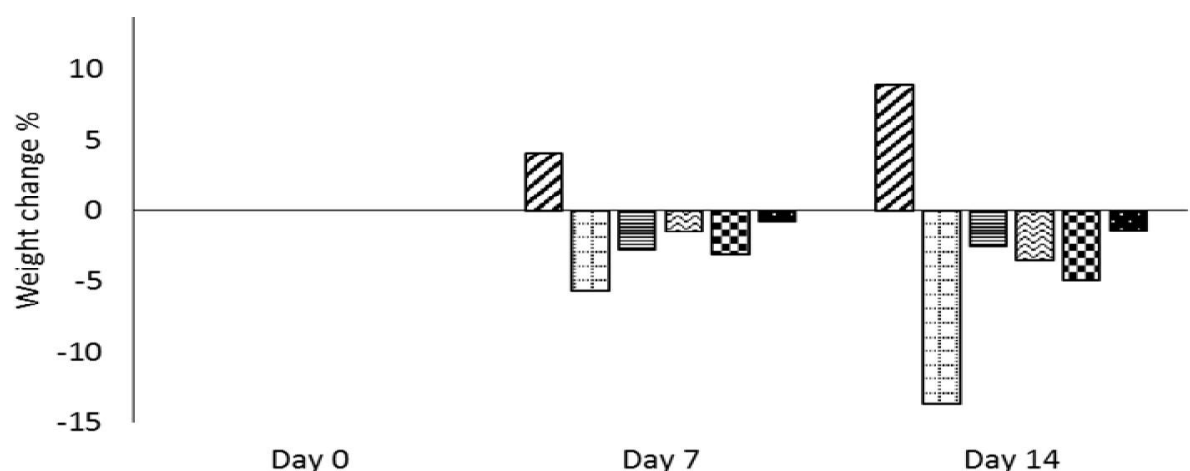

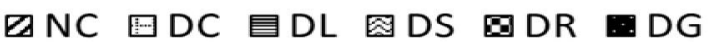

Figure 1: Weight change of (a) normoglycaemic rats treated with $100 \mathrm{mg} / \mathrm{kg}$ methanol leaf, stem and root extracts of Ageratum conyzoides and (b) streptozotocin-induced diabetic rats treated with $100 \mathrm{mg} / \mathrm{kg}$ methanol leaf, stem and root extracts of Ageratum conyzoides. Values are presented as mean $\pm \mathrm{SD}(\mathrm{n}=6)$ for each group. Values are statistically significant compared to control group at $p<0.05$. NC - normal control, NL normoglycaemic+leaf, NS - normoglycaemic+stem, NR - normoglycaemic+root, NG normoglycaemic+glibenclamide, NC - normal control, DC - diabetic control, DL - diabetic+leaf, NS diabetic+stem, DR - diabetic+root, DG - diabetic+glibenclamide

\section{Effect of methanol extracts of Ageratum conyzoides on serum lipids}

There was significant $(p<0.05)$ reduction in total cholesterol (TC), triglycerides (TG) and low density lipoprotein cholesterol (LDL-C) concentrations of all diabetic groups treated with extracts when compared with the negative control (Table 3). High density lipoprotein cholesterol (HDL-C) concentration was significantly $(p<0.05)$ increased in treated 
diabetic group in comparison with the negative control.

\section{Effect of methanol extracts of Ageratum conyzoides on rat body weight}

Generally, there was decline in the weights of streptozotocin-induced diabetic rats but treatment with the extracts shows ameliorative effect (Figure 1). There was significant $(p<0.05)$ improvement in the body weight of treated diabetic groups compared with the diabetic control; the final body weights of streptozotocin induced diabetic rats treated with the extracts were significantly increased $(p<0.05)$ in comparison with the diabetic control.

\section{DISCUSSION}

Plant based herbal drugs are emerging as the primary components of holistic approaches to diabetes management. Recently, the search for appropriate hypoglycaemic agents using animal models in diabetes research has been focused on plants used in traditional medicine partly because of leads provided by traditional medicines to natural products that may be better treatment than the currently used drugs $[2,3]$.

Phytochemical components have been implicated as responsible for some anti-diabetic activity of some plant extracts [2,4]. These natural components may act separately or synergistically to cause the global hypoglycaemic effect [2]. In the present study, phytochemicals of antidiabetic importance found in Ageratum conyzoides include alkaloids, carbohydrates, cardiac glycosides, flavonoids, saponins, tannins, steroids and triterpenes. Alkaloids inhibit $\alpha$ glucosidase and decrease glucose transport through the intestinal epithelium.

Flavonoids suppress the glucose level, reduce plasma cholesterol and triglycerides significantly and increase hepatic glucokinase activity probably by enhancing the insulin release from pancreatic islets. Tannin reduce blood glucose level in a dose dependent manner. Triterpenoids and saponins stimulates the release of insulin and blocks the formation of glucose in the blood stream. Cardiac glycosides stimulate insulin secretion form islets cells. Steroids reduced the blood glucose level and restoring the insulin levels $[19,20]$

The reduction observed in fasting blood glucose of treated diabetic rats is in agreement with previous studies [21,22]. Earlier, it has been reported that the mode of reduction in blood glucose could be due to some active phytoconstituents having insulinomimetic or insulin secretagogues activity [23]. The mechanism of action of Ageratum conyzoides could be both pancreatic and extrapancreatic. The latter might involve the stimulation of peripheral glucose utilization. This is in contrast to glibenclamide which stimulates insulin release from the beta-cell of the pancreas and is only efficient when damage to the beta-cell is moderate. Flavonoids, a component of Ageratum conyzoides are known to regenerate the damaged beta-cells in diabetic mice [24,25]. Ageratum conyzoides may also act by preventing the death of $\beta$-cells and/or permit recovery of partially destroyed $\beta$-cells [26].

Several components of plant extracts, such as fibre [27], saponins [28] and flavonoids [29], possess antihyperlipidemic effects. The ability of Ageratum conyzoides extract in reducing serum lipids could be explained on the basis of insulin releasing capacity of its phytoconstituents. Insulin inhibits lipolysis and increases uptake of fatty acids into adipose tissue and triglyceride synthesis. In insulin-deficient diabetes, lipolysis is not inhibited and this results to hyperlipidemia. Lipid abnormalities accompanying atherosclerosis is the major cause of cardiovascular disease in diabetes with high levels of TC and LDL as major coronary risk factors [30]. HDLCholesterol, an antiatherogenic lipoprotein transports cholesterol from peripheral tissues into the liver and thereby acts as a protective factor against coronary heart disease [21]. TC and TG were significantly lowered in diabetic rats treated with leaf and stem extracts of Ageratum conyzoides. LDL-C levels were also significantly lowered in all treated diabetic groups. This was accompanied by a corresponding significant increase in HDL-C (cardioprotective lipid) levels. These results are in agreement with previous findings $[21,31]$.

Type 1 diabetes mellitus is associated with loss of body weight due to increase muscle wasting and loss of tissue proteins. Induction of diabetes with streptozotocin is a simulation of type 1 diabetes. Treatment had significant ameliorative effect on the weights of diabetic rats comparable to the positive control which received the standard drug. This is a clear demonstration of the potential of Ageratum conyzoides in preventing wasting in diabetes mellitus.

\section{CONCLUSION}

The significant activities of Ageratum conyzoides seen in this study may be due to the presence of phytochemicals, such as flavonoids, which have been shown to possess antidiabetic and 
antioxidant properties. Hence, this justifies the use of the plant in traditional medicine for the management of diabetes, and should therefore be further studied as a possible source of a novel antidiabetic drug.

\section{DECLARATIONS}

\section{Acknowledgement}

The authors are grateful to the entire staff of the Animal House, Department of Pharmacy, and the Head of Biochemistry Department, both of Ahmadu Bello University, Zaria, for their support in the course of this research.

\section{Conflict of Interest}

No conflict of interest associated with this work.

\section{Contribution of Authors}

The authors declare that this work was done by the authors named in this article and all liabilities pertaining to claims relating to the content of this article will be borne by them.

\section{Open Access}

This is an Open Access article that uses a funding model which does not charge readers or their institutions for access and distributed under the terms of the Creative Commons Attribution License (http://creativecommons.org/licenses/by/ 4.0) and the Budapest Open Access Initiative (http://www.budapestopenaccessinitiative.org/rea d), which permit unrestricted use, distribution, and reproduction in any medium, provided the original work is properly credited.

\section{REFERENCES}

1. DeFronzo RA. Pharmacologic therapy for type 2 diabetes mellitus. Ann Intern Med, 2000; 133(1): 73-74.

2. Iwuji S, Nwafor A, Egwurugwu J, Chikezie $H$. Antihyperglycaemic Efficacy of Cnidoscolus aconitifolius compared with Glibenclamide in Alloxan-induced Diabetic Wistar Rats. Int Res J Med Sci, 2014; 2(3): 1-4.

3. Asgari S, Setorki M, Rafieian-kopaei M, Heidarian E, Shahinfard N, Ansari R, Forouzandeh Z. Postprandial hypolipidemic and hypoglycaemic effects of Allium hertifolium and Sesamum indicum on hypercholesterolemic rabbits. Afr J Pharm Pharmacol, 2012; 6(15): 1131-1135.

4. Nyunaï N, Abdennebi EH, Bickii J, Manguelle-Dicoum MA. Subacute antidiabetic properties of Ageratum conyzoides leaves in diabetic rats Intl J Pharm Sci Res, 2015; Vol. 6(4): 1378-1387.
5. Adebayo AH, Zeng GZ, Fan JT, He WJ, Xu JJ, Zhang YM, Akindahunsi AA, Kela R, Tan NH. Biochemical, haematological and histopathological studies of extract of Ageratum conyzoides L. in Sprague Dawley rats. J Med Plants Res, 2010; 4(21): 2264-2272.

6. de Melo NI, Magalhaes LG, de Carvalho CE, Wakabayashi KA, de $P$ Aguiar $G$, Ramos $R C$, Mantovani AL, Turatti IC, Rodrigues V, Groppo $M$ et al. Schistosomicidal activity of the essential oil of Ageratum conyzoides L. (Asteraceae) against adult Schistosoma mansoni worms. Molecules, 2011; 16: 762-773.

7. Patil RP, Nimbalkar MS, Jadhav UU, Dawkar VV and Govindwar SP. Antiaflatoxigenic and antioxidant activity of an essential oil from Ageratum conyzoides $L$. J Sci Food Agric, 2010; 90(4): 608-614.

8. Nogueira JHC, Gonçalez E, Galleti SR, Facanali R, Marques MOM, Felício JD. Ageratum conyzoides essential oil as aflatoxin suppressor of Aspergillus flavus. Int J Food Micro, 2010; 137(1): 55-60.

9. Amal MMN, Sami AK, Marcel K, Reto B, Wai EA, Thomas JS. The antiprotozoal activity methylated flavonoids from Ageratum conyzoides L. J Ethnopharm, 2010; 129: 127-130.

10. Neetu A, Sangeeta C, Anita S, Matadeen B, Neera S. Efficacy of Ageratum conyzoides against the control of mosquitoes. Int J Pharm Sci Res, 2011; 2(12): 32353237.

11. Garber JC, Barbee WR, Bielitzki JT, Clayton LA, Donovan JC, Kohn DF, Lipman NS, Locke P, Melcher J, Quimby FW, et al. Guide for the Care and Use of Laboratory Animals. New York: The National Academies Press, 2010; $p 213$.

12. Trease, GE, Evans, WC. Pharmacognosy (12th edn). English Language Book Society, Bailliere Tindall, Britain, 1989; pp 378, 386-480, 774-775.

13. Burcelin R, Eddouks M, Maury J, Kande J, Assan R, Girard J. Excessive glucose production, rather than insulin resistance, accounts for hyperglycaemia in recent-onset Streptozotocin diabetic rats. Diabetologia, 1995; 38: 283-290.

14. Atawodi SE, Yakubu OE, Liman ML, lliemene DU. Effect of methanolic extract of Tetrapleura tetraptera (Schum and Thonn) Taub leaves on hyperglycemia and indices of diabetic complications in alloxan-induced diabetic rats. Asian Pac J Trop Biomed 2014; 4(4): 272-278.

15. Clark L, Lyons C. Development of the first glucose enzyme electrode that rely on a thin layer of glucose oxidase on an oxygen electrode. Ann New York Acad Sci, 1962; 109: 29.

16. Stein EA. Lipids, lipoproteins and Apolipoproteins. In: Treitz, N.W. (Ed). Fundamentals of Clinical Chemistry, 3rd edn, WB Sauders Philadelphia, 1987; pp 470-479.

17. Wacnic RG, Alber JJ. A comprehensive evaluation of the heparin manganese precipitation procedure for estimating high density lipoprotein cholestsrol. J Lipid Res, 1978; 19: 65-76.

18. Friedwald WT. Methods for the determination of $L D L$ Cholesterol. Clin Chem, 1972; 18: 499-502.

Trop J Pharm Res, May 2017; 16(5): 995 
19. Patel DK, Kumar R, Laloo D, Hemalatha S. Natural medicines from plant source used for therapy of diabetes mellitus: an overview of its pharmacological aspects. Asian Pacif J Trop Dis, 2012; 3: 239-250

20. Bhushan MS, Rao CHV, Ojha SK, Vijayakumar M, Verma A. An analytical review of plants for antidiabetic activity with their phytoconstituent \& mechanism of action. Int J Pharm Sci Res, 2010; 1(1): 29-46.

21. Nyunaï N, Abdennebi EH, Bickii J, Manguelle-Dicoum MA. Subacute antidiabetic properties of ageratum conyzoides leaves in Diabetic rats Int J Pharm Sci Res, 2015; Vol. 6(4): 1378-1387.

22. Agbafor KN, Onuohah SC, Ominyi MC, Orinya OF, Ezeani N, Alum E. Antidiabetic, Hypolipidemic and Antiathrogenic Properties of Leaf Extracts of Ageratum conyzoides in Streptozotocin-Induced diabetic rats. Int $J$ Curr Microbiol App Sci, 2015; 4(11): 816-824

23. Patel DK, Prasad SK, Kumar R, Hemalatha S. An overview on antidiabetic medicinal plants having insulin mimetic property. Asian Pac J Trop Biomed, 2012; 2(4): 320-330

24. Ebrahimzadeh MA, Nabavi SM, Nabavi, SF, Eslami B. Antioxidant activity of the bulb and aerial parts of Ornithogalumsintenisii $L$ (Liliaceae) at flowering stage. Trop J Pharm Res, 2010; 9(2): 141-148.

25. Ghosh D, Bera TK, Ali KM. and De D. Antidiabetic and antioxidative effects of aqueous extract of seed of Psoraleacorylifolia (somraji) and seed of Trigonellafoenum-graecum L., (methi) in Separate and composite manner in streptozotocin-induced diabetic male Albino rat. Trop J Pharm Res, 2009; 1(7): 1-10.

26. Atchutkumar K, Satyanarayana T, Raj Kiran K, Rajesh $K$. Antihyperglycemic activity of methanolic extract of Leucas aspera wild whole plant on blood glucose levels of streptozotocin-induced diabetic rats. Int $J$ Pharm Pharm Sci, 2013; 5: 76-78.

27. Arvill A, Bodin L. Effect of Short-term Ingestion of Konjacglucomannanon Serum Cholesterol in Healthy Men. Am J Clin Nutr, 1995; 61: 585-589.

28. Francis G, Kerem Z, Makkar HPS, Beckerm K. The biological action of saponins in animal systems: $A$ Review. Br J Nutr, 2002; 88: 587-605.

29. Song EK, Hur $H$, Han MK. Epigallocatechingallate Prevents Autoimmune Diabetes Induced by Multiple Low Doses of Streptozotocin in Mice. Arch Pharmacol Res, 2003; 26: 559-563.

30. Temme EH, Vaqn HPG, Schouten EG, Kesteloot $H$. Effect of plant sterol-enriched spread on serum lipids and lipoproteins in middly hypercholesterolaemic subjects. Acta Cardiology, 2002; 57: 111-115.

31. Giribabu N, Kumar KE, Rekha SS, Muniandy S, Salleh $N$. Chlorophytum borivilianum root extract maintains near normal blood glucose, insulin and lipid profile levels and prevents oxidative stress in the pancreas of streptozotocin-induced adult male diabetic rats. Int J Med Sci 2014; 11(11):1172-1184. 